\title{
PENGARUH KEPUTUSAN INVESTASI, KEBIJAKAN DIVIDEN DAN KEBIJAKAN HUTANG TERHADAP NILAI PERUSAHAAN SEKTOR PROPERTY, REAL ESTATE DAN BUILDING CONTRUCTIONS YANG TERDAFTAR DI BURSA EFEK INDONESIA PERIODE TAHUN 2016-2018
}

\author{
${ }^{1)}$ Heru Satria Rukmana, ${ }^{2)}$ Rosi Esa Mardiyani \\ ${ }^{1)}$ Dosen Program Studi Manajemen, STIE Dewantara \\ Jl. Raya Pemda Bojong Depok Baru III, Karadenan, Cibinong, Bogor, Jawa Barat 16913,Indonesia \\ Email: heru.satria@dewantara.ac.id \\ ${ }^{2)}$ Alumni Program Studi Manajemen, STIE Dewantara \\ Jl. Raya Pemda Bojong Depok Baru III, Karadenan, Cibinong, Bogor, Jawa Barat 16913,Indonesia \\ Email: rosiesamardiyani@gmail.com
}

\begin{abstract}
This study aims to determine the effect of investment decisions, dividend policy and debt policy on corporate value decisions in the property, real estate and building construction sectors for the period 2016-2018. This research uses quantitative analysis. The coefficient of determination test results where the adjusted rsquare value of the Investment Decision variable (X1), the Dividend Policy variable (X2) and the Debt Policy variable (X3) is 90.5\%, which means that the deterimination coefficient value of the Investment Decision variable (X1), the Dividend Policy variable (X2) ) and the debt policy variable (X3) has a dominant factor affecting the firm value variable $(Y)$. Based on the results of multiple linear regression, the equation $\hat{Y}=-1.972+0.071$ $+0.018+0.602$ is obtained. From the results of hypothesis testing, it states that there is an influence of the Investment Decision (X1), Dividend Policy (X2) and Debt Policy (X3) on Firm Value $(Y)$. The results of the partial t test where the significant value of the Investment Decision variable (X1) is $0.000<0.05$, the significant value of the Dividend Policy variable (X2) is 0.000 $<0.05$ and the significant value of the Debt Policy variable (X3) is $0.022<0.05$.
\end{abstract}

Keywords: Investment, Dividend, Debt, Firm Value.

\begin{abstract}
ABSTRAK
Penelitian ini bertujuan untuk mengetahui pengaruh Keputusan Investasi, Kebijakan Dividen dan Kebijakan Hutang terhadap keputusan Nilai Perusahaan Perusahaan sektor Property, Real Estate dan Building Contructions periode tahun 2016-2018. Hasil uji koefisien determinasi dimana nilai adjusted rsquare variable Keputusan Investasi (X1), variabel Kebijakan Dividen (X2) dan variabel Kebijakan Hutang (X3) sebesar 90.5\%, yang berarti bahwa nilai koefisien deteriminasi variabel Keputusan Investasi (X1), variabel Kebijakan Dividen (X2) dan variable Kebijakan Hutang (X3) mempunyai faktor dominan yang mempengaruhi variable Nilai Perusahaan (Y). Berdasarkan hasil regresi linier berganda didapatkan persamaan $\hat{Y}=-1.972+$ $0.071+0.018+0.602$. Dari hasil pengujian hipotesis menyatakan terdapat pengaruh variabel Keputusan Investasi (X1), Kebijakan Dividen (X2) dan Kebijakan Hutang (X3) terhadap Nilai Perusahaan (Y). Hasil dari uji parsial t dimana nilai signifikan variabel Keputusan Investasi (X1) sebesar $0.000<0.05$, nilai signifikan variabel Kebijakan Dividen (X2) sebesar $0.000<0.05$ dan nilai signifikan variable Kebijakan Hutang (X3) sebesar 0.022<0.05.
\end{abstract}

Kata kunci: Investasi, Dividen, Hutang, Nilai Perusahaan. 


\section{PENDAHULUAN}

\subsection{Latar Belakang}

Persaingan bisnis saat ini menuntut perusahaan-perusahaan yang ada untuk meningkatkan kualitas perusahaan. Hal ini dimaksudkan agar perusahaan dapat tetap bersaing dengan perusahaan-perusahaan lainnya dan dapat meningkatkan nilai perusahaan. Upaya untuk meningkatkan nilai perusahaan merupakan poin yang penting, aspek tersebut dipandang erat kaitannya dengan persepsi investor dan kreditor mengenai prospek yang dimiliki perusahaan. Nilai perusahaan yang dimiliki memberikan gambaran kepada manajemen mengenai persepsi investor tentang kinerja masa lalu dan prospek perusahaan di masa yang akan datang. Oleh sebab itu, perusahaan akan berusaha untuk mengoptimalkan nilai perusahaannya agar memiliki daya tarik di hadapan para investor.

Nilai Perusahaan dalam beberapa literature disebut dengan beberapa istilah diantaranya, Price-To-Book Value yaitu perbandingan antara saham dengan nilai buku saham dan Market-To-Book Ratio yaitu rasio saat ini harga saham dengan nilai buku per saham. Dalam menentukan nilai perusahaan terdapat beberapa faktor yang diantaranya adalah Keputusan Investasi, Kebijakan Dividen dan Kebijakan Hutang.

Salah satu perusahaan yang perkembangannya cukup pesat adalah dari sektor Property, Real Estate dan Building Contructions yang mana seiring berkembangnya zaman semakin banyak proyek-proyek pembangunan yang akan mendirikan perumahan, apartemen, hotel dan lain sebagainya. Berikut data perkembangan sektor Property, Real Estate dan Building Contructions (dalam satuan persen):
Indonesia GDP Annual Growth Rate

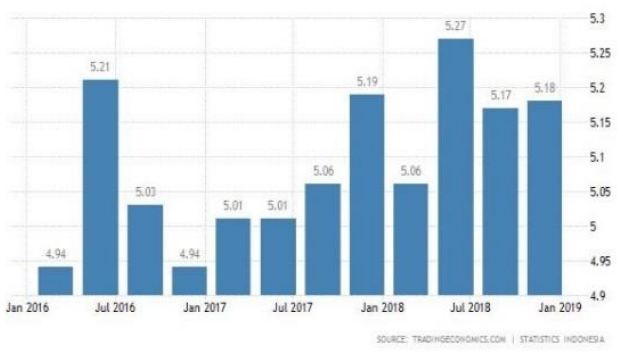

Gambar 1. GDP Annual Growth Rate Property, Real Estate dan Building Contructions

Dari data di atas menunjukan bahwa pertumbuhan perusahaan sektor Property, Real Estate dan Building Contructions saat ini cenderung stabil di kisaran 5,17\%. Meskipun belum setinggi di tahun 2011 silam yang mencapai angka $6,8 \%$. Namun cukup mengindikasikan bahwa kondisinya masih cukup stabil. Angka ini juga sudah lebih baik dibanding pertumbuhan pada tahun 2015 yang hanya sebesar 4,8\%. Namun dalam perkembangan perusahaan Property, Real Estate dan Building Contructions yang terus meningkat ini dan tentunya persaingan pun semakin ketat untuk meningkatkan nilai perusahaannya.

Berdasarkan latar belakang tersebut penulis ingin melakukan penelitian dengan judul penelitian "Pengaruh Keputusan Investasi, Kebijakan Dividen, Dan Kebijakan Hutang Terhadap Nilai Perusahaan Sektor Property, Real Estate Dan Building Contructions Yang Terdaftar Di Bursa Efek Indonesia Periode Tahun 2016-2018".

\subsection{Rumusan Masalah}

Berdasarkan latar belakang yang telah diuraikan di atas, maka peneliti merumuskan masalah

1. Bagaimana keputusan investasi berpengaruh terhadap nilai perusahaan sektor Property, Real Estate dan Building Contructions yang terdaftar di 
Bursa Efek Indonesia periode tahun 2016-2018?

2. Bagaimana kebijakan dividen berpengaruh terhadap nilai perusahaan sektor Property, Real Estate dan Building Contructions yang terdaftar di Bursa Efek Indonesia periode tahun 2016-2018?

3. Bagaimana kebijakan hutang berpengaruh terhadap nilai perusahaan sektor Property, Real Estate dan Building Contructions yang terdaftar di Bursa Efek Indonesia periode tahun 2016-2018?

4. Manakah variabel yang paling dominan antara keputusan investasi, kebijakan dividen dan kebijakan hutang dalam menentukan nilai perusahaan sektor Property, Real Estate dan Building Contructions yang terdaftar di Bursa Efek Indonesia periode tahun 2016-2018?

\subsection{Tujuan Penelitian}

Berdasarkan latar belakang dan perumusan masalah yang telah dikemukakan diatas maka tujuan yang ingin dicapai pada penelitian adalah:

1. Untuk mengetahui dan menganalisis apakah keputusan investasi berpengaruh terhadap nilai perusahaan sektor Property, Real Estate dan Building Contructions yang terdaftar Di Bursa Efek Indonesia periode tahun 2016-2018.

2. Untuk mengetahui dan menganalisis apakah kebijakan dividen berpengaruh terhadap nilai perusahaan sektor Property, Real Estate dan Building Contructions yang terdaftar di Bursa Efek Indonesia periode tahun 20162018.

3. Untuk mengetahui dan menganalisis apakah kebijakan hutang berpengaruh terhadap nilai perusahaan sektor Property, Real Estate dan Building Contructions yang terdaftar di Bursa
Efek Indonesia periode tahun 20162018.

4. Untuk mengetahui dan menganalisis manakah variabel yang paling dominan antara keputusan investasi, kebijakan dividen dan kebijakan hutang dalam menentukan nilai perusahaan sektor Property, Real Estate dan Building Contructions yang terdaftar di Bursa Efek Indonesia periode tahun 20162018.

\section{TINJAUAN PUSTAKA}

\subsection{Landasan Teori}

\subsubsection{Akuntansi}

Menurut Samryn (2012:3) definisi akuntansi secara umum merupakan suatu sistem informasi yang digunakan untuk mengubah data dari transaksi menjadi informasi keuangan. Proses akuntansi meliputi kegiatan mengidentifikasi, mencatat, dan menafsirkan, mengomunikasikan peristiwa ekonomi dari sebuah organisasi kepada pemakai infromasinya. Proses akuntansi menghasilkan informasi keuangan. Semua proses tersebut diselenggarakan secara tertulis berdasarkan bukti transaksi yang juga harus tertulis.

Transkasi yang dimaksud dalam akuntansi meliputi peristiwa-peristiwa atau kejadian yang mempengaruhi proses keuangan organisasi yang bersangkutan. Baik dilihat dari jenis usaha maupun bentuk badan hukum, yang akan diakuntansikan dalam sebuah organisasi bisnis adalah kekayaan yang dikenal dengan istilah aktiva, utang yang dikenal dengan istilah liabilitas, modal yang dikenal sebagai ekuitas.

\subsubsection{Laporan Keuangan}

Menurut IAI (2017:1.3) laporan keuangan adalah suatu penyajian terstruktur dari posisi keuangan dan kinerja keuangan suatu entitas. Tujuan laporan keuangan adalah memberikan informasi mengenai posisi keuangan, kinerja keuangan, dan arus 
kas entitas yang bermanfaat bagi sebagian besar pengguna laporan keuangan dalam pembuatan keputusan ekonomik. Laporan keuangan juga menunjukan hasil pertanggungjawaban manajemen atas penggunaan sumber daya yang dipercayakan kepada mereka.

Tujuan laporan keuangan sebagai berikut:

a. Memberikan informasi kas yang dapat dipercaya mengenai posisi keuangan perusahaan pada saat tertentu.

b. Memberikan informasi keuangan yang dapat dipercaya mengenai hasil usaha perusahaan selama periode akuntansi tertentu.

c. Memberikan informasi yang dapat membantu pihak-pihak yang berkepentingan untuk menilai atau menginterpretasikan kondisi dan potensi suatu perusahaan.

d. Memberikan informasi penting lainnya yang relevan dengan kebutuhan pihakpihak yang berkepentingan dengan laporan keuangan yang bersangkutan.

\subsubsection{Keputusan Investasi}

Menurut Jogiyanto Hartono (2013:5) Investasi adalah penundaan konsumsi sekarang untuk dimasukkan ke aktiva produktif selama periode waktu yang tertentu. Walaupun pengorbanan konsumsi sekarang dapat diartikan sebagai investasi untuk konsumsi dimasa mendatang, tetapi pengertian investasi yang lebih luas membutuhkan aktiva yang produkif untuk mengubah satu unit konsumsi yang ditunda untuk dihasilkan menjadi lebih dari satu unit konsumsi mendatang.

Menurut Sudana (2011:6) keputusan investasi berkaitan dengan proses pemilihan satu atau lebih investasi yang dinilai menguntungkan dari sejumlah alternatif investasi yang tersedia bagi perusahaan. Hasil dari keputusan investasi yang diambil oleh manajemen perusahaan akan tampak di neraca sisi aset, yaitu berupa aset lancar dan aset tetap.
Keputusan investasi dalam penelitian ini diproksikan dengan Price Earnings Ratio (PER). Menurut Sartono dalam Aji (2012) Price Earnings Ratio (PER) merupakan perbandingan antara harga pasar suatu saham (market price) dengan Earnings Per Share (EPS) dari saham yang bersangkutan.

\subsubsection{Kebijakan Dividen}

Menurut Ambarwati Ari, Dwi Sri (2010:64) Kebijakan Dividen adalah kebijakan yang diambil manajemen perusahaan untuk memutuskan membayarkan sebagian keuntungan perusahaan kepada pemegang saham daripada menahannya sebagai laba ditahan untuk diinvestasikan kembali pendapatannya dalam jangka panjang.

Menurut Sartono (2010:281) kebijakan dividen sering dianggap sebagai signal dalam menilai baik buruknya perusahaan, hal ini disebabkan karena kebijakan dividen dapat membawa pengaruh terhadap harga saham perusahaan. Kebijakan dividen dalam penelitian ini diukur menggunakan Dividen Payout Ratio (DPR). Dividend Payout Ratio (DPR) dihitung dengan cara membandingkan antara dividen yang dibagi dengan laba bersih yang didapatkan dan biasanya disajikan dalam bentuk persentase.

\subsubsection{Kebijakan Hutang}

Menurut Brigham and Houston (2011:78) hutang adalah sumber pendanaan eksternal yang diperoleh perusahaan untuk menjalankan operasionalnya. Kebijakan hutang perusahaan merupakan tindakan manajemen perusahaan yang akan mendanai perusahaan dengan menggunakan modal yang berasal dari hutang. kebijakan hutang merupakan kebijakan mengenai keputusan yang diambil perusahaan untuk menjalankan operasionalnya dengan menggunakan hutang keuangan atau financial leverage.

Dalam penelitian ini ukuran debt ratio merupakan proxy dari kebijakan hutang 
perusahaan. Debt Equity Ratio (DER) dapat diukur dengan total hutang atau total kewajiban dibagi dengan modal pemegang saham (kekayaan bersih atau ekuitas).

\subsubsection{Nilai Perusahaan}

Menurut Setiani (2013) Nilai perusahaan merupakan penilaian investor tentang seberapa baik kondisi suatu perusahaan dan kondisi ini dapat tercermin melalui harga pasar saham perusahaan. Sedangkan menurut Hermungsih (2011:61) dalam buku yang ditulis oleh Heru Satria Rukmana Nilai Perusahaan merupakan persepsi investor terhadap perusahaan, yang sering dikaitkan dengan harga saham. Nilai Perusahaan dalam beberapa literature disebut dengan beberapa istilah diantaranya, Price-To-Book Value yaitu perbandingan antara saham dengan nilai buku saham dan Market-To-Book Ratio yaitu rasio saat ini harga saham dengan nilai buku per saham. Nilai buku (Book Value) per lembar saham menunjukan aktiva bersih (Net Assets) yang dimiliki oleh pemegang saham.

Dalam penelitian ini, untuk mengukur nilai perusahaan menggunakan Price To Book Value (PBV), rasio ini berfungsi untuk mengidentifikasi saham mana yang harganya wajar, terlalu rendah (Undervalued) dan terlalu tinggi (Overvalued). Cara ini mengaitkan rasio PBV dengan nilai intrinsik saham yang diperkirakan berdasarkan model penilaian saham.

\subsection{Kerangka Pemikiran}

Untuk faktor Keputusan Investasi dengan menghitung Price Earningss Ratio (PER), untuk faktor Kebijakan Dividen Kerangka pemikiran menggambarkan hubungan dari variabel independen yaitu Keputusan Investasi, Kebijakan Dividen dan Kebijakan Hutang terhadap variabel dependen yaitu nilai perusahaan. Kerangka pemikiran dapat dilihat pada gambar berikut ini :

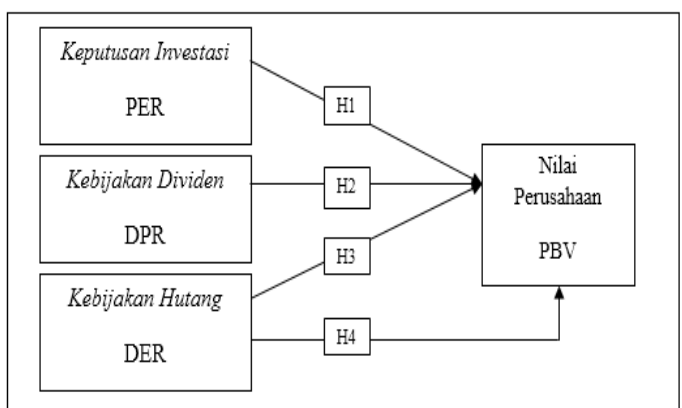

\section{Gambar 2. Kerangka Pemikiran}

\subsection{Hipotesis}

Menurut Sugiono (2012:70) Hipotesis diartikan sebagai jawaban sementara tehadap rumusan masalah penelitian. Hipotesis merupakan anggapan dasar yang kemudian membuat suatu teori yang masih harus diuji kebenarannya.

H0 : Tidak adanya pengaruh antara variabel independen (X) dengan variabel dependen $(\mathrm{Y})$.

Ha1: Keputusan Investasi berpengaruh positif dan signifikan terhadap Nilai Perusahaan.

Ha2: Kebijakan Dividen berpengaruh positif dan signifikan terhadap Nilai Perusahaan.

Ha3: Kebijakan Hutang berpengaruh positif dan signifikan terhadap Nilai Perusahaan.

\section{METODE PENELITIAN}

\subsection{Jenis Penelitian}

Jenis penelitian ini adalah penelitian kuantitatif, menurut Sugiyono (2013:13) metode penelitian kuantitatif dapat diartikan sebagai metode penelitian yang digunakan untuk meneliti pada populasi atau sampel tertentu. teknik pengambilan sampel pada umumnya dilakukan secara random, pengumpulan data menggunakan instrumen penelitian, analisis data bersifat kuantitatif/statistik dengan tujuan menguji hipotesis yang telah ditetapkan.

Jenis penelitian ini adalah Kausalitas. Menurut Sugiyono (2015) penelitian asosiatif kausalitas merupakan penelitian 
yang bertujuan untuk mengetahui hubungan sebab akibat dua variabel atau lebih.

\subsection{Variabel Penelitian}

Dalam penelitian ini variabel-variabel yang digunakan adalah deskriptif. Variabel bebas pada penelitian ini adalah keputusan investasi, kebijakan dividen, kebijakan hutang dan variabel terikat adalah nilai perusahaan.

\subsection{Lokasi dan Waktu Penelitian}

Penelitian ini dilakukan dengan penelurusan data laporan keuangan perusahaan sektor Property, Real Estate, dan Building Contructions yang terdaftar di Bursa efek Indonesia dilakukan sejak November 2019-Februari 2020.

\subsection{Objek Penelitian}

Objek penelitian pada penelitian ini adalah data Laporan Keuangan Tahunan perusahaan sektor Property, Real Estate, dan Building Contructions yang terdaftar di Bursa Efek Indonesia periode tahun 2016-2018.

\subsection{Populasi dan Sampel}

\subsubsection{Populasi}

Populasi penelitian ini adalah seluruh data laporan keuangan perusahaan sektor Property, Real Estate dan Building Contructions yang tercatat di Bursa Efek Indonesia dan website resmi perusahaan untuk memberikan informasi laporan keuangan.

Teknik pengambilan sampel dengan purposive sampling, yaitu Purposive Sampling dengan pertimbangan tertentu. Perusahaan-perusahaan yang masuk dalam sampel penelitian ini berjumlah 16 perusahaan.

Perusahaan-perusahaan yang masuk dalam sampel penelitian ini berjumlah 16 perusahaan yang di antaranya :

1. Bekasi Fajar Industrial Estate Tbk

2. Ciputra Development Tbk

3. Puradelta Lestari Tbk
4. Gowa Makasar Tourism Dev Tbk

5. Perdana Gapuraprima Tbk

6. Lippo Karawaci Tbk

7. PP Properti Tbk

8. Agung Podomoro Land Tbk

9. Alam Sutera Realty Tbk

10. Bumi Serpong Damai Tbk

11. Intiland Development Tbk

12. Metropolitan Kentjana Tbk

13. Jaya Kontruksi Manggala Pratama Tbk

14. Nusa Raya Cipta Tbk

15. PP Persero Tbk

16. Wijaya Karya (Persero) Tbk

Kriteria yang dimaksudkan dalam pemilihan perusahaan untuk sampel penelitian ini adalah sebagai berikut :

a. Perusahaan sektor Property, Real Estate dan Building Contructions yang terdaftar di Bursa Efek Indonesia secara berturut-turut periode tahun 2016-2018.

b. Perusahaan Property, Real Estate dan Building Contructions yang menerbitkan laporan keuangannya secara kontinyu selama periode tahun 2016-2018.

c. Perusahaan Property, Real Estate dan Building Contructions yang membagikan dividennya secara berkala periode tahun 2016-2018.

d. Ketersediaan dan kelengkapan data selama penelitian.

\subsection{Teknik Pengumpulan Data}

Penelitian ini menggunakan jenis data dokumenter yaitu berupa jurnal penelitian terdahulu, literatur dan laporan keuangan perusahaan. Sumber data yang digunakan adalah data sekunder. Data sekunder merupakan sumber data yang diperoleh secara tidak langsung melalui media perantara atau diperoleh dan dicatat oleh pihak lain berupa bukti, catatan yang telah tersusun dalam arsip data dokumenter yang dipublikasikan. Pengumpulan data yang diperlukan berupa data total hutang dan total modal sendiri, data dividend per share 
dan earnings per share, data harga saham, dan nilai buku per lembar saham. Seluruh data diperoleh dari Indonesia Stock Exchange (IDX).

\subsection{Teknik Analisis Data}

Penelitian ini menggunakan teknik analisis regresi berganda karena variabel independen dalam penelitian lebih dari dua variabel.

\section{HASIL DAN PEMBAHASAN}

\subsection{Uji Normalitas}

Menurut Ghozali (2011:160) Uji Normalitas bertujuan untuk menguji apakah model regresi, variabel terikat dan variabel bebas keduanya memiliki distribusi data normal atau tidak.

\section{Tabel 1. Hasil Uji Normalitas}

One-Sample Kolmogorov-Smirnov Test

\begin{tabular}{|ll|r|}
\hline & & $\begin{array}{r}\text { Unstandardiz } \\
\text { ed Residual }\end{array}$ \\
\hline $\mathrm{N}$ & 16 \\
Normal Parameters & Mean & .0000000 \\
Most Extreme Differences & Std. Deviation & 1.35252803 \\
& Absolute & .117 \\
& Positive & .117 \\
Test Statistic & Negative & -.101 \\
Asymp. Sig. (2-tailed) & & .117 \\
\hline
\end{tabular}

a. Test distribution is Normal.

b. Calculated from data

c. Lilliefors Significance Correction.

d. This is a lower bound of the true significance.

Sumber: Data Diolah 2020

Berdasarkan hasil uji normalitas pada tabel 1, dapat diketahui nilai Kolmogorov Smirnov sebesar 0.117 dan nilai signifikansi sebesar 0.200 yang berarti lebih besar dari 0.05, maka dapat disimpulkan data berdistribusi normal.

\subsection{Uji Autokorelasi}

Model regresi yang baik adalah regresi yang bebas dari autokorelasi. Untuk mengetahui ada tidanya autokorelasi perlu dilakukan pengujian terlebih dahulu dengan menggunakan statistik Durbin Watson (D-W).

Tabel 2. Hasil Uji Autokorelasi

Model Summary
\begin{tabular}{|l|c|r|r|r|r|}
\hline Model & R & R Square & $\begin{array}{c}\text { Adjusted R } \\
\text { Square }\end{array}$ & $\begin{array}{c}\text { Std. Error of } \\
\text { the Estimate }\end{array}$ & $\begin{array}{c}\text { Durbin- } \\
\text { Watson }\end{array}$ \\
\hline 1 & $.961^{\mathrm{a}}$ & .924 & .905 & 1.51217 & 2.629 \\
\hline
\end{tabular}
a. Predictors: (Constant), Kebijakan Hutang 3 Tahun, Keputusan Investasi 3 Tahun,
Kebijakan Dividen 3 Tahun
b. Dependent Variable: Nilai Perusahaan 3 Tahun

Sumber: Data Diolah 2020

Berdasarkan hasil uji autokorelasi pada tabel di atas menunjukkan bahwa nilai Durbin Watson adalah 2.629. Dari tabel Durbin Watson yang diperoleh, nilai batas bawah $(\mathrm{dl})$ sebesar 0.85718 dan nilai batas atas (du) sebesar 1.72773 pada tingkat signifikansi 0.05 . Nilai DW sebesar 2.629 lebih besar dari batas atas (du) yakni 1.72773 sehingga dapat disimpulkan bahwa tidak terjadi autokorelasi.

\subsection{Uji Multikolinearitas}

Menurut Ghozali (2011:105) Uji Multikolinieritas bertujuan untuk menguji apakah dalam model regresi ditemukan adanya korelasi antara variabel independen.

Tabel 3. Hasil Uji Multikolinearitas

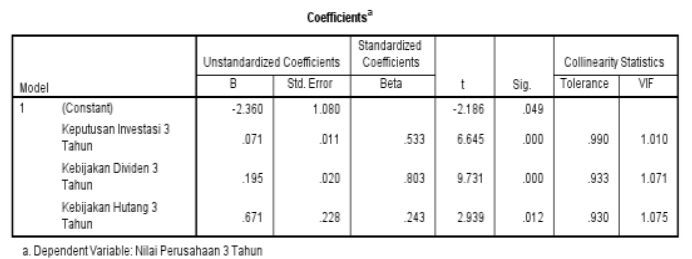

Sumber: Data Diolah 2020

Berdasarkan hasil uji multikolinieritas pada tabel 3. menunjukkan nilai Tolerance variabel keputusan investasi sebesar 0.990, nilai Tolerance variabel kebijakan dividen sebesar 0.933, nilai Tolerance kebijakan hutang sebesar 0.930 yang lebih besar dari 0.05 (Tolerance > 0.05) dan nilai VIF variabel keputusan investasi sebesar 1.010, nilai VIF variabel kebijakan dividend sebesar 1.071 dan nilai VIF variabel 
kebijakan hutang sebesar 1.075 yang lebih kecil dari 10 (VIF < 10). Dengan Demikian dapat disimpulkan bahwa seluruh variabel bebas dalam penelitian ini tidak terjadi Multikolinieritas.

\subsection{Uji Heterokedastisitas}

Menurut Ghozali (2011:139) Uji Heteroskedastisitas bertujuan menguji apakah dalam model regresi terjadi ketidaksamaan varians residual dari satu pengamatan ke pengamatan yang lain.

Tabel 4. Hasil Uji Heterokedastisitas

\begin{tabular}{|c|c|c|c|c|c|c|}
\hline \multicolumn{7}{|c|}{ coe } \\
\hline \multirow[b]{2}{*}{ Model } & & \multicolumn{2}{|c|}{ Unstandardized Coefficients } & \multirow{2}{*}{$\begin{array}{c}\text { Standardized } \\
\text { Coefficients } \\
\text { Beta }\end{array}$} & \multirow[b]{2}{*}{$\mathrm{t}$} & \multirow[b]{2}{*}{ sig. } \\
\hline & & B & Std. Error & & & \\
\hline 1 & (Constant) & 1.403 & 566 & & 2.480 & .029 \\
\hline & $\begin{array}{l}\text { Keputusan Investasi } 3 \\
\text { Tahun }\end{array}$ & .000 & .006 & .016 & -.059 & .954 \\
\hline & $\begin{array}{l}\text { Kebjiakan Dividen } 3 \\
\text { Tahun }\end{array}$ & -.016 & .011 & -.416 & -1.524 & .153 \\
\hline & $\begin{array}{l}\text { Kebijiakan Hutang } 3 \\
\text { Tahun }\end{array}$ & -.069 & .120 & -158 & -.577 & .574 \\
\hline
\end{tabular}

Sumber: Data Diolah 2020

$\begin{array}{ccr}\text { Berdasarkan } & \text { hasil uji } \\ \text { heteroskedastisitas } & \text { pada tabel } & 4\end{array}$ menunjukkan bahwa nilai probabilitas signifikansi variabel keputusan investasi sebesar $0.954>0.05$, nilai probalitias signifikansi variabel kebijakan dividen sebesar $0.153>0.05$ dan nilai probabilitas signifikansi variabel kebijakan hutang sebesar $0.574>0.5$. Dengan demikian dapat disimpulkan bahwa dalam penelitian ini tidak terjadi Heteroskedastisitas dalam model regresi.

\subsection{Analisis Regresi Linier Berganda}

Tabel 5. Hasil Analisis Regresi Linier Berganda Periode Tahun 2016-2018

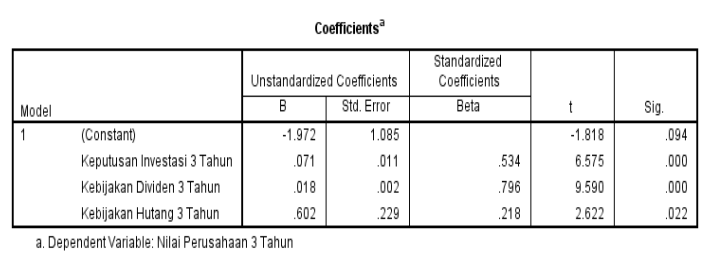

Sumber: Data Diolah 2020

Persamaan analisis regresi berganda diatas dapat dijelaskan sebagai berikut: a. Konstanta sebesar -1.972. Artinya jika variabel keputusan investasi $\left(\mathrm{X}_{1}\right)$, kebijakan dividen $\left(\mathrm{X}_{2}\right)$ dan kebijakan hutang $\left(\mathrm{X}_{3}\right)$ nilainya adalah 0 , maka variabel nilai perusahaan $(\mathrm{Y})$ nilainya adalah -1.972 .

b. Koefisien regresi variabel keputusan investasi $\left(\mathrm{X}_{1}\right)$ sebesar 0.071. Artinya jika variabel kebijakan dividen $\left(X_{2}\right)$ dan kebijakan hutang $\left(\mathrm{X}_{3}\right)$ nilainya tetap dan variabel keputusan investasi $\left(\mathrm{X}_{1}\right)$ mengalami kenaikan $1 \%$, maka nilai perusahaan $(\mathrm{Y})$ akan mengalami peningkatan sebesar 0.071. Koefisien bernilai positif artinya terjadi hubungan positif antara keputusan investasi $\left(\mathrm{X}_{1}\right)$ dengan nilai perusahaan (Y). semakin naik keputusan investasi $\left(\mathrm{X}_{1}\right)$ maka semakin meningkat nilai perusahaan (Y).

c. Koefisien regresi variabel kebijakan dividen $\left(\mathrm{X}_{2}\right)$ sebesar 0.018. Artinya jika variabel keputusan investasi $\left(\mathrm{X}_{1}\right)$ dan kebijakan hutang $\left(\mathrm{X}_{3}\right)$ nilainya tetap dan variabel kebijakan dividen $\left(\mathrm{X}_{2}\right)$ mengalami kenaikan $1 \%$, maka nilai perusahaan $(\mathrm{Y})$ akan mengalami peningkatan sebesar 0.018. Koefisien bernilai positif artinya terjadi hubungan positif antara kebijakan dividen $\left(\mathrm{X}_{2}\right)$ dengan nilai perusahaan (Y). semakin naik kebijakan dividen $\left(\mathrm{X}_{2}\right)$ maka semakin meningkat nilai perusahaan (Y).

d. Koefisien regresi variabel kebijakan Hutang $\left(\mathrm{X}_{3}\right)$ sebesar 0.602. Artinya jika variabel keputusan investasi $\left(\mathrm{X}_{1}\right)$ dan kebijakan dividen $\left(\mathrm{X}_{2}\right)$ nilainya tetap dan variabel kebijakan hutang $\left(\mathrm{X}_{3}\right)$ mengalami kenaikan $1 \%$, maka nilai perusahaan $(\mathrm{Y})$ akan mengalami peningkatan sebesar 0.602. Koefisien bernilai positif artinya terjadi hubungan positif antara kebijakan hutang $\left(\mathrm{X}_{3}\right)$ dengan nilai perusahaan (Y). semakin naik kebijakan hutang $\left(\mathrm{X}_{3}\right)$ maka semakin meningkat nilai perusahaan $(\mathrm{Y})$. 


\subsection{Uji Hipotesis}

\subsubsection{Uji t (Parsial)}

Menurut Ghozali (2016:133) Uji

Statistik $t$ (parsial) pada dasarnya menunjukkan seberapa jauh pengaruh satu variable independen secara individual dalam menerangkan variasi variabel independen.

Tabel 6. Hasil Uji t (Parsial)

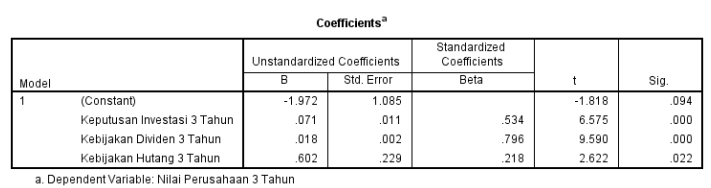

Sumber: Data Diolah 2020

a. Pengujian Hipotesis Ha1

Ha1 : Keputusan Investasi berpengaruh positif dan signifikan terhadap Nilai Perusahaan.

Berdasarkan hasil tabel 6 diperoleh hasil bahwa variabel keputusan investasi memiliki nilai $\mathrm{t}$ signifikansi sebesar 0.000 lebih kecil dari 0.05 . Sehingga hipotesis Ha1 diterima.

b. Pengujian Hipotesis Ha2

Ha2 : Kebijakan Dividen berpengaruh positif dan signifikan terhadap Nilai Perusahaan.

Berdasarkan hasil tabel 6 diperoleh hasil bahwa variabel kebijakan dividen memiliki nilai $\mathrm{t}$ signifikansi sebesar 0.000 lebih kecil dari 0.05 Sehingga hipotesis $\mathrm{Ha} 2$ diterima.

c. Pengujian Hipotesis Ha3

Ha3 : Kebijakan Hutang berpengaruh positif dan signifikan terhadap Nilai Perusahaan.

Berdasarkan hasil tabel 6 diperoleh hasil bahwa variabel kebijakan hutang memiliki nilai $\mathrm{t}$ signifikansi sebesar 0.022 lebih kecil dari 0.05. Sehingga hipotesis Ha3 diterima.

\subsubsection{Uji F (Silmutan)}

Anwar Sanusi

mengemukakan bahwa uji keseluruhan koefisien regresi linier secara bersamasama.

Tabel 7. Hasil Uji F (Silmutan)

ANOVA $^{\text {a }}$
\begin{tabular}{|ll|r|r|r|l|l|}
\hline Model & & Sum of Squares & \multicolumn{1}{|c|}{ df } & Mean Square & F & Sig. \\
\hline 1 & Regression & 331.314 & 3 & 110.438 & 47.058 & $.000^{b}$ \\
& Residual & 28.162 & 12 & 2.347 & & \\
& Total & 359.476 & 15 & & & \\
\hline
\end{tabular}
a. Dependent Variable: Nilai Perusahaan 3 Tahun
b. Predictors: (Constant), Kebijakan Hutang 3 Tahun, Keputusan Investasi 3 Tahun, Kebijakan Dividen
3 Tahun

Sumber: Data Diolah 2020

Berdasarkan tabel 7 diperoleh hasil nilai signifikansi $F$ sebesar 0.000. Nilai signifikansi lebih kecil dari 0.05 , hal ini menunjukkan bahwa keputusan investasi, kebijakan dividen dan kebijakan hutang secara simultan berpengaruh terhadap nilai perusahaan pada perusahaan Property, Real Estate dan Building Contructions yang terdaftar di Bursa Efek Indonesia pada tahun 2016-2018.

\subsection{Uji Koefisien Determinasi $\left(r^{2}\right)$}

Koefisien Determinasi
dimaksudkan untuk mengetahui tingkat ketepatan paling baik dalam analisa regresi dimana hal yang ditunjukan oleh besarnya koefisien determinasi $\left(r^{2}\right)$ antara 0 dan 1 . Koefisien determinasi nol variabel independen sama sekali tidak berpengaruh terhadap variabel dependen.

Apabila koefisien determinasi semakin satu, maka dapat dikatakan bahwa variabel independen berpengaruh terhadap variabel dependen. Selain itu koefisien determinasi dipergunakan untuk mengetahui presentase kebutuhan variabel dependen yang disebabkan oleh variabel independen.

Tabel 8. Hasil Uji Koefisien Determinasi $\left(\mathbf{r}^{2}\right)$

Model Summary
\begin{tabular}{|l|c|c|c|c|c|}
\hline Model & R & R Square & $\begin{array}{c}\text { Adjusted R } \\
\text { Square }\end{array}$ & $\begin{array}{c}\text { Std. Error of } \\
\text { the Estimate }\end{array}$ & $\begin{array}{c}\text { Durbin- } \\
\text { Watson }\end{array}$ \\
\hline 1 & $.961^{\text {a }}$ & .924 & .905 & 1.51217 & 2.629 \\
\hline
\end{tabular}
a. Predictors: (Constant), Kebijakan Hutang 3 Tahun, Keputusan Investasi 3 Tahun,
Kebijakan Dividen 3 Tahun
b. Dependent Variable: Nilai Perusahaan 3 Tahun

Sumber: Data Diolah 2020 
Berdasarkan hasil tabel di atas dapat dijelaskan bahwa Variabel Keputusan Investasi $\left(\mathrm{X}_{1}\right)$, Kebijakan Dividen $\left(\mathrm{X}_{2}\right)$ dan Kebijakan Hutang $\left(\mathrm{X}_{3}\right)$ memiliki kontribusi sebesar $90,5 \%$ terhadap Nilai Perusahaan (Y). Sedangkan sisanya 9,5\% dipengaruhi oleh faktor lain yang tidak diteliti dalam penelitian ini.

\section{KESIMPULAN DAN SARAN}

\subsection{Kesimpulan}

1. Berdasarkan nilai perhitungan uji koefisien determinasi pada penelitian ini periode tahun 2016-2018 dengan nilai adjusted $r$ square variabel keputusan investasi, kebijakan dividen dan kebijakan hutang sebesar $90.5 \%$. Dapat disimpulkan bahwa nilai koefisien determinasi variabel independen mempunyai faktor dominan variabel dependen pada penelitian ini.

2. Berdasarkan nilai perhitungan uji asumsi klasik yang terdiri dari uji normalitas, uji autokorelasi, uji multikolinieritas dan uji heteroskedastisitas yang sudah dilakukan dalam penelitian ini periode tahun 2016-2018 menunjukkan hasil nilai uji normalitas sebesar $0.200>$ 0.05 menunjukkan data dalam penelitian berdistribusi normal. Hasil nilai uji autokorelasi Nilai DW sebesar 2.629 lebih besar dari batas atas $(\mathrm{du})$ yakni 1.72773 sehingga menunjukkan bahwa tidak terjadi autokorelasi. Hasil nilai uji multikolinieritas dengan nilai Tolerance lebih besar dari 0.05 dan nilai VIF lebih kecil dari 10 menunjukkan bahwa data dalam penelitian ini tidak terjadi multikolinieritas. Dan Hasil nilai uji heteroskedastisitas dengan nilai probabilitas signifikansi dari semua variabel independen lebih besar dari 0.05 menunjukkan bahwa data dalam penelitian tidak terjadi heteroskedastisitas dalam model regresi.

3. Berdasarkan nilai perhitungan analisis regresi linier berganda yang sudah dilakukan dalam penelitian ini periode tahun 2016-2018 menunjukkan nilai koefisien regresi keputusan investasi sebesar 0.071, nilai koefisien regresi kebijakan dividen sebesar 0.018 , nilai koefisien regresi kebijakan hutang sebesar 0.602 dan nilai konstanta sebesar -1.972.

4. Berdasarkan hasil analisis data menggunakan uji parsial $\mathrm{t}$ periode tahun 2016-2018 dalam penelitian ini dapat disimpulkan nilai signifikan keputusan investasi sebesar 0.000 , nilai signifikan kebijakan dividen sebesar 0.000 dan nilai signifikan kebijakan hutang sebesar 0.022 lebih kecil dari 0.05 yang berarti terdapat pengaruh dari keputusan investasi, kebijakan dividen dan kebijakan hutang terhadap nilai perusahaan.

5. Berdasarkan hasil analisis data menggunakan uji simultan $\mathrm{F}$ periode tahun 2016-2018 dalam penelitian ini nilai signifikan $\mathrm{F}$ sebesar 0.000 lebih kecil dari 0.05 yang berarti terdapat pengaruh keputusan investasi, kebijakan dividen dan kebijakan hutang terhadap nilai peru

\subsection{Saran}

1. Bagi Perusahaan-Perusahaan Property, Real Estate dan Building Contructions dan calon investor yang ingin berinvestasi pada saham, sebaiknya lebih mempertimbangkan dan meningkatkan faktor keputusan investasi dan kebijakan dividen karena faktor tersebut memiliki pengaruh yang signifikan terhadap nilai perusahaan pada perusahaan Property, Real Estate dan Building Contructions yang terdaftar di Bursa Efek Indonesia pada tahun 2016-2018. 
2. Bagi calon investor yang ingin menginvestasikan sahamnya pada perusahaan tidak hanya berpatokan pada hutang suatu perusahaan. Tapi juga melihat dari aspek investasi, dividen dan laba pada suatu perusahaan.

3. Peneliti selanjutnya perlu memperpanjang periode penelitian, sehingga akan diperoleh gambaran yang lebih jelas tentang kondisi pasar terutama Sektor Property, Real Estate dan Building Contructions di Indonesia

\section{DAFTAR PUSTAKA}

Agus, R. Sartono. 2010. Manajemen Keuangan Teori Dan Aplikasi. Edisi Keempat. Yogyakarta: BPFE.

Aji, Meygawan Nurseto. 2012. Analisis Faktor-Faktor yang Mempengaruhi Price Earning Ratio (Studi Empiris pada Perusahaan Manufaktur yang Terdaftar di Bursa Efek Indonesia 2007-2010). Jurnal. Fakultas Ekonomi Universitas Diponegoro.

Andinata,W. 2010. Analisis Pengaruh Profitabilitas dan Kebijakan Dividen Terhadap Nilai Perusahaan Manufaktur di Bursa Efek Indonesia. Journal of Accounting Diponegoro University.

Ari Ambarwati, Sri Dwi. 2010. Manajemen Keuangan Lanjut. Graha Ilmu Yogyakarta.

Brigham, E.F dan Joel Houston. 2011. Dasar-Dasar Manajemen Keuangan Terjemahan. Edisi 10. Jakarta: Salemba Empat.

Darmawan, Wira Adi. 2013. Analisis Pengaruh Kebijakan Hutang, Profitabilitas dan Kebijakan Dividen Terhadap Nilai Perusahaan (Pada Perusahaan Manufaktur Yang Terdaftar di BEI Periode 2009-2011). Universitas Semarang.

Fahmi, Irham dan Yovi Lavianti Hadi. 2011. Teori Portofolio dan Analisis
Investasi Teori Soal dan Jawab. Bandung: Cetakan kedua. Alfabeta, CV.

Ghozali, Imam, 2016. Aplikasi Analisis Multivariate dengan Program IBM SPSS 23. (edisi delapan). Semarang: BP Universitas Diponegoro.

Ghozali, Imam, 2011. Aplikasi Analisis Multivariate dengan Program IBM SPSS 19. Semarang: Badan Penerbit UNDIP.

Hartono, Jogiyanto. 2013. Teori Portofolio Dan Analisis Investasi Edisi Kedelapan. Yogyakarta: BPFE.

Ikatan Akuntan Indonesia. 2017. Standar Akuntansi Keuangan. Penerbit Ikatan Akuntan Indonesia. Jakarta.

Indahningrum, Rizka Putri dan Ratih Handayani. 2009. Pengaruh Kepemilikan Manajerial, Kepemilikan Institusional, Deviden, Pertumbuhan Perusahaan, Free Cash Flow dan Profitabilitas terhadap Kebijakan Hutang Perusahaan Jurnal Bisnis dan Akuntansi. vol.11 No 3 Hlm 189-207. Jurnal. Kampus STIE Trisakti.

Mahendra DJ, Alfredo. 2011. Pengaruh Kinerja Keuangan Terhadap Nilai Perusahaan (Kebijakan Dividen Sebagai Variabel Moderating) Pada Perusahaan Manufaktur Di Bursa Efek Indonesia. Tesis diterbitkan. Bali: Universitas Udayana.

Martikarini, Nani. 2014. Pengaruh Profitabilitas, Kebijakan Hutang, dan Dividen terhadap Nilai Perusahaan Manufaktur yang terdaftar di Bursa Efek Indonesia. Skripsi. Depok: FE Universitas Gunadarma.

Nadhiroh, U. 2013. Studi Empiris Keputusan-Keputusan Dividen, Investasi, dan Pendanaan Eksternal pada Perusahaan-Perusahaan Indonesia yang Go Public di Bursa Efek Indonesia. Jurnal Otonomi.

Rahmawati, Apriliana Nuzul. 2012. Analisis Faktor Kebijakan Hutang Yang Mempengaruhi Nilai Perusahaan 
(Studi Pada Perusahaan Manufaktur Yang Terdaftar di BEI Periode 20062010). Skripsi Program Sarjana

Fakultas Ekonomi dan Bisnis

Universitas Diponegoro.

Riyanto, Bambang. 2010. Dasar-Dasar

Pembelanjaan Perusahaan. Edisi

Keempat. Cetakan Ke Sepuluh.

Yogyakarta: BPFE.

Samryn, L.M. 2011. Pengantar Akuntansi 